НАУКОВИЙ ВІСНИК

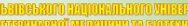

The

cientific messegger of Livi National University
Veterinary Medicine and Biotechnologies

(1)

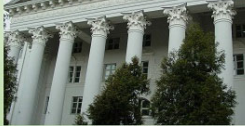

Том 21 № 91

2019
Науковий вісник Дьвівського національного університету ветеринарної медицини та біотехнологій імені С.3. Гжицького. Серія: Сільськогосподарські науки

Scientific Messenger of Lviv National University of Veterinary Medicine and Biotechnologies. Series: Agricultural sciences

ISSN 2519-2698 print

https://nvlvet.com.ua/index.php/agriculture

doi: $10.32718 /$ nvlvet-a9120

UDC 636.2.082

\title{
Evaluation of the reproductive ability of cows of different production types of the simmental breed
}

\author{
T.V. Orikhivskyi ${ }^{1}$, V.V. Fedorovych ${ }^{2}$, N.P. Mazur ${ }^{3}$ \\ ${ }^{1}$ Stepan Gzhytskyi National University of Veterinary Medicine and Biotechnologies Lviv, Ukraine \\ ${ }^{2}$ Institute of Animal Breeding and Genetics nd. a. M.V. Zubets of National Academy of Agrarian Science of Ukraine, \\ Chubynske, Ukraine \\ ${ }^{3}$ Institute of animal biology NAAS, Lviv, Ukraine
}

Article info

Received 23.09.2019

Received in revised form 21.10.2019

Accepted 22.10.2019

Stepan Gzhytskyi National University of Veterinary Medicine and Biotechnologies Lviv, Pekarskaya Str., 50, Lviv, 79010, Ukraine.

Institute of Animal Breeding and Genetics nd. a. M.V. Zubets of National Academy of Agrarian Science of Ukraine, Pohrebnyaka Str., 1, Chubynske, Boryspil region, Kyiv district, 08321, Ukraine.

Institute of animal biology NAAS, Vasyl Stus Str., 38, Lviv, 79034, Ukraine.

Tel.: +38-032-270-23-89

E-mail:logir@ukr.net
Orikhivskyi, T.V., Fedorovych, V.V., \& Mazur, N.P. (2019). Evaluation of the reproductive ability of cows of different production types of the simmental breed. Scientific Messenger of Lviv National University of Veterinary Medicine and Biotechnologies. Series: Agricultural sciences, 21(91), 111115. doi: 10.32718/nvlvet-a9120

In today 's conditions of intensive cattle breeding, the improvement of the reproductive qualities of cows has significant practical and scientific interest since reproductive function impairment of cattle, shortens the period of its economic use, lowers the level of dairy productivity and therefore the profitability of the livestock industry as a whole. In this respect the reproductive metrics studying of cows of different production types of Simmental breed is important. Researches were held at agricultural limited liability company "Litinske" in the Drohobych district of Lviv oblast. It is established that the average age of the first insemination of Simmental breed animals was 549 days or 18.1 months, age of first calving - 827.3 days or 27.2 months, and the live weight in the specified physiological periods -453.7 and respectively $529.1 \mathrm{~kg}$. The duration of pregnant heifers was 278.4 days, and the duration of the service period of cows, depending on lactation, was within 89.7-94.4, the interval period - within 371.8-375.1 and the dry periodwithin 73.1-73.5 days. Indicators of reproductive capacity of animals depend on their production type. In particular, the first insemination and the first calving of animals of dairy production type occurred later than of animals of meat and dairy and meat types. However, heifers of dairy production type were smaller live weight during these periods compared to animals of other production types. It is found that the shortest duration of pregnancy and the longest duration of service and inter service periods were characterized by cows of dairy production type. The strength of impact of production type of animals on age of the first insemination accounted for $11.5 \%$ of the total phenotypic variability on the age of the first calving - 9,9\%, on the duration of the service period $-7.8-11.0 \%$, inter-calving $-4.8-10.4 \%$, and on the duration of the body and the dry period was insignificant and unbelievable.

Key words: simmental breed, production type, cows, age and live weight at first insemination, age and live weight at first calving, duration of service, inter-calving and dry periods, power of influence.

\section{Оцінка відтворювальної здатності корів різних виробничих типів симентальської породи}

\author{
Т.В. Оріхівський${ }^{1}$ В.В. Федорович ${ }^{2}$, Н.П. Мазур ${ }^{3}$ \\ ${ }^{1}$ Львівський національний університет ветеринарної медицини та біотехнологій імені С.3. Гжицького, \\ м. Львів, Україна \\ ${ }^{2}$ Інститут розведення і генетики тварин імені М.В. Зубия НААН, Чубинське, Украӥна \\ ${ }^{3}$ Інститут біології тварин НААН, м. Львів, Україна
}


У сучасних умовах інтенсивного ведення скотарства питання покращення відтворювальних якостей корів представляє значний як практичний, так науковий інтерес, оскільки порушення відтворних функиій у великої рогатої худоби, скорочує термін ї̈ господарського використання, знижує рівень молочної продуктивності, а отже рентабельність галузі скотарства в иілому. У цьому аспекті значний інтерес представляє вивчення показників відтворювальної здатності корів різних виробничих типів симентальської породи. Дослідження проведені у СГТзОВ “Літинське” Дрогобииького району Львівської області. Встановлено, щчо середній вік першого осіменіння корів симентальської породи становив 549 днів або 18,1 місяия, а вік першого отелення - 827,3 дня або 27,2 місяия, тривалість тільності при изьому становила 278,4 дня. У телиць симентальської породи жива маса при першому осіменінні становила 453,7 к2, а при першому отеленні- 529,1 кг. Тривалість сервіс-періоду у корів, залежно від лактації, знаходилася в межах 89,7-94,4, міжотельного - в межах 371,8-375,1 та сухостійного - 73,1-73,5 дня. Показники відтворювальної здатності тварин залежать від їх виробничого типу. Зокрема, перше осіменіння та перше отелення тварин молочного виробничого типу відбувалося пізніше, ніж у особин молочно-м'ясного та м'ясо-молочного типів. Однак, телиці молочного виробничого типу мали меншу живу масу у зазначені періоди порівняно з тваринами інших виробничих типів. Виявлено, щзо найкоротшою тривалістю тільності та найдовщою тривалістю сервіс- й міжстельного періодів характеризувалися корови молочного виробничого типу. Сила впливу виробничого типу тварин на вік першого осіменіння становила 11,5\% від загальної фенотипової мінливості, на вік першого отелення - 9,9\%, на тривалість сервіс-періоду - 7,8-11,0\%, міжотельного - 4,8-10,4\%, а на тривалість тільності й сухостійного періоду була незначною і невірогідною.

Ключові слова: симентальська порода, виробничий тип, корови, вік першого осіменіння, вік першого отелення, жива маса, показники відтворювальної здатності, сила впливу.

\section{Вступ}

Найважливішими складовими успішного ведення галузі молочного скотарства є висока молочна продуктивність корів у поєднанні з доброю їх відтворювальною здатністю. Оптимальне поєднання цих показників $є$ критерієм співвідношення “генотипсередовище", що характеризує ступінь пристосованості популяції, стада або окремої тварини до певних виробничо-технологічних умов (Zubets, 2003; Kuziv \& Fedorovych, 2016; Babik, 2018; Crowe et al., 2018). У сучасних умовах інтенсивного ведення скотарства питання покращення відтворювальних якостей корів представляє значний як практичний, так науковий інтерес, оскільки порушення відтворних функцій у великої рогатої худоби, скорочує термін іїі господарського використання, знижує рівень молочної продуктивності, а отже рентабельність галузі скотарства в цілому (Berry et al., 2014; Bolgova, 2014; Shcherbatyy et al., 2017).

Покращення показників відтворювальної здатності корів лише селекційними методами здійснити дуже важко, оскільки рівень їх успадковуваності є низьким. Однак, ряд вчених зазначають, що відтворна функція тварин залежить від генотипових факторів, зокрема приналежності до породи, типу, лінії тощо і тому добір за показниками відтворювальної здатності $\epsilon$ доцільним (Stavetska \& Rudyk, 2012; Crowe \& Williams, 2012).

Високими адаптаційними властивостями, що вироблялися впродовж століть, характеризуються тварини симентальської породи. Крім того, як корови, так і бугаї цієї породи відзначаються хорошою відтворювальною здатністю (Burkat et al., 1998). На даний час у структурі симентальської породи існує чотири виробничих типи (молочний, молочно-м'ясний, м'ясомолочний та м'ясний), господарськи корисні ознаки яких вивчені недостатньо. 3 огляду на зазначене, метою наших досліджень було провести оцінку показників відтворювальної здатності корів різних виробничих типів даної породи.

\section{Матеріал і методи досліджень}

Дослідження проведені у СГТзОВ “Літинське" Дрогобицького району Львівської області на коровах симентальської породи. До вибірки залучено 161 повновікову корову із закінченою третьою лактацією. Розподіл корів на виробничі типи проводили за методикою, описаною 3. Айсановым (Aysanov, 1997).

Оцінку відтворювальної здатності корів здійснювали за віком першого осіменіння та першого отелення, тривалістю тільності, сухостійного, сервіс- та міжотельного періодів за першу, другу, третю та вищу лактації.

За допомогою однофакторного дисперсійного аналізу вивчали силу впливу виробничого типу корів на показники їх відтворювальної здатності.

Отримані результати досліджень обробляли методом варіаційної статистики за ГФ. Лакиным (Lakin, 1990) 3 використанням комп'ютерної програми "Excel" та "STATISTICA-6,1". Результати середніх значень вважали статистично вірогідними при $\mathrm{P}<0,05(*$ або $), \mathrm{P}<0,01\left(* * \mathrm{aбo}^{2}\right), \mathrm{P}<0,001\left(* * *\right.$ або $\left.{ }^{3}\right)$.

\section{Результати та їх обговорення}

У зоотехнічній практиці відтворювальну здатність корів на популяційному рівні оцінюють за віком першого осіменіння та першого отелення, тривалістю сухостійного, сервіс- і міжотельного періодів, тривалістю тільності тощо. Одним із найбільш важливих показників, що характеризує вирощування ремонтного молодняку та подальшу молочну продуктивність тварин $є$ вік першого осіменіння телиць. Він обумовлює помітний вплив на ефективність подальшого господарського використання корів. В умовах інтенсивного молочного скотарства інтерес до цього питання зростає, оскільки цей показник впливає на економічні показники галузі і результативність селекційно-племінної роботи (Fedorovych, 2017).

Встановлено, що середній вік першого осіменіння корів симентальської породи, які увійшли у вибірку, становив 549 днів або 18,1 місяця. 3 віком першого плідного осіменіння тісно пов'язаний вік першого отелення тварин. У піддослідних тварин середній вік 
першого отелення становив 827,3 дня або 27,2 місяця, тривалість тільності нетелей при цьому становила 278,4 дня.

Для забезпечення нормальної відтворювальної функції тварин, народження здорового приплоду і високої майбутньої молочної продуктивності корів важливе значення має їх жива маса при першому осіменінні та першому отеленні. Вважається, що жива маса телиць при першому осіменінні повинна становити не менше 75\% від живої маси дорослої корови. У підконтрольних телиць жива маса при першому осіменінні становила 453,7 кг, а при першому отеленні цей показник у тварин становив 529,1 кг.

Наступними не менш важливими ознаками відтворювальної здатності корів $є$ тривалість сервіс- та міжотельного періодів. Сервіс-період є періодом фізіологічного циклу кожної корови, впродовж якого вона повинна бути підготовлена до плідного осіменіння. Тривалість сервіс-періоду, як виробничого показника, дає загальне уявлення про відтворювальну функцію як стада в цілому, так і кожної корови зокрема (Fedorovych, 2017). Серед вчених і практиків до цих пір немає єдиної думки щодо оптимальної тривалості сервіс-періоду (Sudarev, 2008), хоча існує класичне визначення цього періоду, згідно 3 яким його тривалість повинна становити 80 днів. Зарубіжні вчені вважають оптимальним час від отелення до запліднення на рівні 80-90 днів, оскільки в стадах саме 3 такою тривалістю сервіс-періоду виробництво молока $\epsilon$ найбільш рентабельним, причому незалежно від рівня надою (Heringstad et. al., 2006).

Встановлено, що тривалість сервіс-періоду піддослідних корів була близькою до оптимальної і певним чином залежала від їх віку (табл. 1).

\section{Таблиця 1}

Відтворювальна здатність корів симентальської породи

\begin{tabular}{lcccccccc}
\hline \multirow{2}{*}{ Лактація } & \multicolumn{7}{c}{ Тривалість періоду: } \\
\cline { 2 - 9 } & \multicolumn{2}{c}{ тільності } & \multicolumn{2}{c}{ сервіс } & \multicolumn{2}{c}{ міжотельного } & \multicolumn{2}{c}{ сухостійного } \\
\cline { 2 - 10 } & $\mathrm{M} \pm \mathrm{m}$, дні & $\mathrm{Cv}, \%$ & $\mathrm{M} \pm \mathrm{m}$, дні & $\mathrm{Cv}, \%$ & $\mathrm{M} \pm \mathrm{m}$, дні & $\mathrm{Cv}, \%$ & $\mathrm{M} \pm \mathrm{m}$, дні & $\mathrm{Cv}, \%$ \\
\hline Перша & $278,4 \pm 0,48$ & 2,2 & $94,4 \pm 1,98$ & 26,5 & $375,1 \pm 1,98$ & 5,0 & - & - \\
Друга & $280,8 \pm 0,34$ & 1,6 & $90,0 \pm 1,63$ & 22,9 & $372,9 \pm 1,66$ & 5,7 & $73,5 \pm 1,60$ & 27,6 \\
Третя & $282,9 \pm 0,35$ & 1,6 & $89,7 \pm 1,60$ & 22,6 & $371,8 \pm 1,76$ & 6,0 & $73,1 \pm 2,00$ & 34,6 \\
Вища & $281,7 \pm 0,40$ & 1,8 & $91,3 \pm 1,82$ & 25,4 & $373,1 \pm 1,94$ & 6,6 & $72,9 \pm 1,75$ & 30,5 \\
\hline
\end{tabular}

Найвищою тривалістю сервіс-періоду характеризувалися первістки. У корів 3 другою лактацією цей показник знизився на 4,4, а 3 третьою - на 4,7 дня. Подібна тенденція спостерігалася за тривалістю міжотельного періоду у корів у зв'язку з тим, що цей період прямо залежить від тривалості попереднього. Найдовший міжотельний період відмічено також у первісток, а у корів $з$ другою та третьою лактаціями він знизився на 2,2 та 3,3 дня. Тривалість сухостійного періоду у корів, залежно від віку, знаходилася в межах 73,1-73,5 дня.

Щодо тривалості тільності, то з віком тварин цей показник подовжувався. Найкоротшою тільністю відзначалися первістки.

Окремої уваги заслуговує рівень коефіцієнтів мінливості досліджуваних ознак відтворювальної здатності корів. Найвищою мінливістю характеризувалася тривалість сервіс- та сухостійного періодів, що свідчить про те, що ці періоди детермінуються переважно середовищними чинниками, тоді як тривалість тільності є генетично зумовленим періодом, на що вказують низькі значення коефіцієнтів мінливості.

Встановлено, що від виробничого типу тварин залежить вік їх першого осіменіння й першого отелення (табл. 2). Зокрема, перше осіменіння телиць молочного виробничого типу відбувалося на 13,5 дня $(\mathrm{P}<0,01)$ пізніше, ніж у особин молочно-м'ясного та на 28,7 дня $(\mathrm{P}<0,001)$ - ніж у тварин м'ясомолочного типу, а перше отелення - на 12,4 (Р < 0,01) та 25,8 дня $(\mathrm{P}<0,001)$ відповідно. Однак, телиці молочного виробничого типу мали меншу живу масу у зазначені періоди порівняно з тваринами інших виробничих типів.

\section{Таблиця 2}

Вік та жива маса при першому осіменінні й першому отеленні корів різних виробничих типів, $\mathrm{M} \pm \mathrm{m}$

\begin{tabular}{|c|c|c|c|c|c|c|}
\hline \multirow{3}{*}{ Показник } & \multicolumn{6}{|c|}{ Виробничий тип тварин } \\
\hline & \multicolumn{2}{|c|}{ молочний $(\mathrm{n}=45)$} & \multicolumn{2}{|c|}{ молочно-м’ясний $(\mathrm{n}=94)$} & \multicolumn{2}{|c|}{ м'ясо-молочний $(\mathrm{n}=22)$} \\
\hline & $\mathrm{M} \pm \mathrm{m}$ & $\mathrm{Cv}, \%$ & $\mathrm{M} \pm \mathrm{m}$ & $\mathrm{Cv}, \%$ & $\mathrm{M} \pm \mathrm{m}$ & $\mathrm{CV}, \%$ \\
\hline Вік першого осіменіння, дні & $560,8 \pm 3,11$ & 3,7 & $547,3 \pm 2,63 * *$ & 4,7 & $532,1 \pm 6,04 * * *$ & 5,2 \\
\hline місяці & $18,4 \pm 0,27$ & 3,7 & $18,0 \pm 0,18$ & 4,7 & $17,5 \pm 0,35^{*}$ & 5,2 \\
\hline Вік першого отелення, дні & $838,1 \pm 3,05$ & 2,4 & $825,7 \pm 2,56^{* *}$ & 3,0 & $812,3 \pm 6,20 * * *$ & 3,5 \\
\hline місяці & $27,6 \pm 0,28$ & 2,4 & $27,1 \pm 0,18$ & 3,0 & $26,7 \pm 0,34^{*}$ & 3,5 \\
\hline Жива маса при І осіменінні, кг & $424,1 \pm 3,25$ & 5,0 & $432,1 \pm 1,7^{* *}$ & 4,3 & $447,3 \pm 3,41^{* * *}$ & 5,2 \\
\hline Жива маса при І отеленні, кг & $524,1 \pm 2,43$ & 2,3 & $530,3 \pm 1,7^{*}$ & 2,7 & $542,9 \pm 4,03 * * *$ & 3,7 \\
\hline
\end{tabular}

Примітка: достовірність різниці показників вказана при порівнянні до тварин молочного виробничого типу 
Їх жива маса при першому осіменінні була нижчою, ніж у телиць молочно-м'ясного типу на 8,0 ( $\mathrm{P}<0,01)$ та м'ясо-молочного - на 23,2 кг ( $\mathrm{P}<0,001)$, а при першому отеленні - на 6,2 (P $<0,05)$ та 18,8 кг ( $<0,001)$ відповідно.

У корів різних виробничих типів спостерігалася така ж зміна тривалості тільності з віком, як і в цілому по стаду. Встановлено міжгрупову диференціацію за цим показником (табл. 3). Зокрема, виявлено, що найкоротшою тривалістю тільності характеризувалися корови молочного виробничого типу, а найдовшою тварини м'ясо-молочного виробничого типу. Проте різниця за цим показником між коровами різних виробничих типів здебільшого була недостовірною.
Найдовшою тривалістю сервіс- та міжотельного періодів відзначалися тварини молочного типу. Їх перевага над ровесницями молочно-м'ясного та м'ясо-молочного типів за тривалістю сервіс-періоду, залежно від віку, становила 7,7-14,0 та 17,9-23,1 дня, а за тривалістю міжотельного періоду - 7,3-13,7 та 15,9-21,9 дня. Слід зазначити, що різниця за цими показниками між тваринами вищенаведених груп здебільшого була вірогідною (Р < 0,05-0,001). Щодо тривалості сухостійного періоду, то за цим показником між тваринами різних виробничих типів достовірної різниці не виявлено.

\section{Таблиця 3}

Відтворювальна здатність корів різних виробничих типів

\begin{tabular}{|c|c|c|c|c|c|c|c|c|}
\hline \multirow{3}{*}{ Лактація } & \multicolumn{8}{|c|}{ Тривалість періоду: } \\
\hline & \multicolumn{2}{|c|}{ тільності } & \multicolumn{2}{|c|}{ сервіс- } & \multicolumn{2}{|c|}{ міжотельного } & \multicolumn{2}{|c|}{ сухостійного } \\
\hline & $\mathrm{M} \pm \mathrm{m}, д н і$ & $\mathrm{Cv}, \%$ & $\mathrm{M} \pm \mathrm{m}$, дні & $\mathrm{Cv}, \%$ & $\mathrm{M} \pm \mathrm{m}$, дні & $\mathrm{Cv}, \%$ & $\mathrm{M} \pm \mathrm{m}$, дні & $\mathrm{Cv}, \%$ \\
\hline \multicolumn{9}{|c|}{ Молочний тип $(n=45)$} \\
\hline Перша & $277,3 \pm 0,88$ & 2,1 & $102,2 \pm 4,50$ & 29,5 & $382,4 \pm 4,69$ & 8,2 & - & - \\
\hline Друга & $280,2 \pm 0,62$ & 1,5 & $100,7 \pm 3,22$ & 21,4 & $383,5 \pm 3,28$ & 5,7 & $77,4 \pm 3,37$ & 29,2 \\
\hline Третя & $282,7 \pm 0,72$ & 1,7 & $96,6 \pm 2,89$ & 20,0 & $378,3 \pm 3,17$ & 5,6 & $69,4 \pm 3,91$ & 37,7 \\
\hline Вища & $280,6 \pm 0,92$ & 2,2 & $102,2 \pm 3,68$ & 24,1 & $382,9 \pm 3,98$ & 7,0 & $71,9 \pm 3,71$ & 34,5 \\
\hline \multicolumn{9}{|c|}{ Молочно-м'ясний тип $(n=94)$} \\
\hline Перша & $278,5 \pm 0,68$ & 2,4 & $94,2 \pm 2,34$ & 29,5 & $375,1 \pm 2,29$ & 5,9 & - & - \\
\hline Друга & $280,9 \pm 0,47$ & 1,6 & $86,7 \pm 2,03^{3}$ & 22,8 & $369,8 \pm 2,10^{3}$ & 5,5 & $73,5 \pm 1,94$ & 25,6 \\
\hline Третя & $283,1 \pm 0,41$ & 1,4 & $88,9 \pm 2,19^{1}$ & 23,8 & $370,9 \pm 2,42$ & 6,3 & $74,5 \pm 3,00$ & 40,7 \\
\hline Вища & $282,0 \pm 0,47$ & 1,6 & $88,9 \pm 2,31^{2}$ & 25,2 & $371,1 \pm 2,49^{1}$ & 6,5 & $74,7 \pm 2,32$ & 30,5 \\
\hline \multicolumn{9}{|c|}{ М'ясо-молочний тип $(n=22)$} \\
\hline Перша & $280,2 \pm 0,72^{1}$ & 1,2 & $79,1 \pm 2,92^{3}$ & 16,9 & $360,5 \pm 2,67^{3}$ & 3,4 & - & - \\
\hline Друга & $281,5 \pm 0,85$ & 1,4 & $82,2 \pm 2,75^{3}$ & 15,3 & $364,5 \pm 2,81^{3}$ & 3,5 & $65,1 \pm 4,07$ & 28,6 \\
\hline Третя & $283,3 \pm 1,09$ & 1,8 & $78,7 \pm 2,28^{3}$ & 13,3 & $362,4 \pm 3,13^{3}$ & 3,9 & $74,6 \pm 3,82$ & 23,5 \\
\hline Вища & $282,4 \pm 0,89$ & 1,4 & $79,3 \pm 2,45^{3}$ & 14,1 & $361,4 \pm 2,64^{3}$ & 3,3 & $71,3 \pm 3,20$ & 20,5 \\
\hline
\end{tabular}

Примітка: достовірність різниці показників вказана при порівнянні до тварин молочного виробничого типу

Таблиця 4

Сила впливу виробничого типу на ознаки відтворювальної здатності

\begin{tabular}{|c|c|c|c|}
\hline Ознака & $\eta^{2} x_{x} \pm m_{\eta}, \%$ & $\mathrm{~F}$ & $\mathrm{P}<$ \\
\hline Вік першого осіменіння & $11,6 \pm 1,25 * * *$ & 10,4 & 0,001 \\
\hline Вік першого отелення & $9,9 \pm 1,25 * * *$ & 8,7 & 0,001 \\
\hline \multicolumn{4}{|c|}{ Перша лактація } \\
\hline Тривалість: тільності & $2,1 \pm 1,27$ & 1,7 & 0,186 \\
\hline сервіс-періоду & $7,8 \pm 1,26 * * *$ & 6,7 & 0,002 \\
\hline міжотельного періоду & $7,0 \pm 1,26^{* * *}$ & 5,9 & 0,003 \\
\hline \multicolumn{4}{|c|}{ Друга лактація } \\
\hline Тривалість: тільності & $0,7 \pm 1,27$ & 0,6 & 0,563 \\
\hline сервіс-періоду & $11,0 \pm 1,26 * * *$ & 9,7 & 0,001 \\
\hline міжотельного періоду & $10,4 \pm 1,25 * * *$ & 9,2 & 0,001 \\
\hline сухостійного періоду & $3,4 \pm 1,26^{*}$ & 2,8 & 0,067 \\
\hline \multicolumn{4}{|c|}{ Третя лактація } \\
\hline Тривалість: тільності & $0,4 \pm 1,27$ & 0,3 & 0,725 \\
\hline сервіс-періоду & $7,9 \pm 1,26 * * *$ & 6,2 & 0,003 \\
\hline міжотельного періоду & $4,8 \pm 1,26^{* *}$ & 4,0 & 0,019 \\
\hline сухостійного періоду & $0,8 \pm 1,27$ & 0,7 & 0,521 \\
\hline \multicolumn{4}{|c|}{ Вища лактація } \\
\hline Тривалість: тільності & $1,9 \pm 1,27$ & 1,6 & 0,212 \\
\hline сервіс-періоду & $10,5 \pm 1,25 * * *$ & 9,3 & 0,001 \\
\hline міжотельного періоду & $7,9 \pm 1,26^{* * *}$ & 6,8 & 0,002 \\
\hline сухостійного періоду & $0,2 \pm 1,54$ & 0,1 & 0,885 \\
\hline
\end{tabular}

Примітка: число ступенів свободи організованого фактора - 2, неорганізованого - 158 
Однофакторним дисперсійним аналізом встановлено, що найсуттєвіше і високодостовірно $(\mathrm{P}<0,001)$ виробничий тип тварин впливав на вік першого осіменіння та тривалість сервіс- і міжотельного періодів (табл. 4).

Сила впливу виробничого типу тварин на тривалість тільності й сухостійного періоду була незначною і невірогідною.

\section{Висновки}

Встановлено, що середній вік першого осіменіння тварин симентальської породи становив 549 днів або 18,1 місяця, вік першого отелення - 827,3 дня або 27,2 місяця, а жива маса у зазначені фізіологічні періоди відповідно 453,7 та 529,1 кг. Тривалість тільності нетелей при цьому становила 278,4 дня, а тривалість сервіс-періоду у корів, залежно від лактації, знаходилася в межах 89,7-94,4, міжотельного періоду - в межах 371,8-375,1 та сухостійного - в межах 73,173,5 дня.

Ознаки відтворювальної здатності тварин залежать від їх виробничого типу. Зокрема, перше осіменіння та перше отелення тварин молочного виробничого типу відбувалося пізніше, ніж у особин молочном'ясного та м'ясо-молочного типів. Однак, телиці молочного виробничого типу мали меншу живу масу у зазначені періоди порівняно 3 тваринами інших виробничих типів.

Виявлено, що найкоротшою тривалістю тільності та найдовшою тривалістю сервіс- й міжотельного періодів характеризувалися корови молочного виробничого типу. Сила впливу виробничого типу тварин найсуттєвішою (Р < 0,001) була на вік першого осіменіння та тривалість сервіс- й міжотельного періодів, а на тривалість тільності й сухостійного періоду - незначною і невірогідною.

Перспективи подальших досліджень. У подальшому буде вивчено зв'язок відтворювальної здатності корів різних виробничих типів з їх молочною продуктивністю.

\section{References}

Aysanov Z. (1997). Opredelenie proizvodstvennyih tipov krupnogo rogatogo skota molochnyih porod. Molochnoe i myasnoe skotovodstvo, 1, 29-30 (in Russian).

Babik, N.P. (2018). Productive longevity of cows of dairy breeds depending on the duration of their first service period. Scientific Messenger of Lviv National University of Veterinary Medicine and Biotechnologies, 20(84), 9-15. doi: 10.15421/nvlvet8402 (in Ukrainian).

Berry, D.P., Wall, E., \& Pryce, J.E. (2014). Genetics and genomics of reproductive performance in dairy and beef cattle. Animal, 8(1), 105-121. doi: 10.1017/S1751731114000743.

Bolgova, N.V. (2014). Vidtvorjuval'na zdatnist' koriv ukrains'koi chorno-rjaboi molochnoi porody. Visnyk Sums'kogo nacional'nogo agrarnogo universitetu. Serija "Tvarynnyctvo", 2/1(24), 15-18 (in Ukrainian).

Burkat, V.P., Havruk, O.F., Podoba, B.Je., Sasin, M.I., \& Ivanenko, I.O. (1998). Symental's'ka poroda. Pleminni resursy Ukrai'ny: nauk. redaktory M.V. Zubec', V.P. Burkat, 36-40 (in Ukrainian).

Crowe, M.A. \& Williams, E.J. (2012). Triennial lactation symposium: effects of stress on postpartum reproduction in dairy cows. Journal Animal Science, 90(5), 1722-1727. doi: 10.2527/jas.2011-4674.

Crowe, M.A., Hostens, M., \& Opsomer, R. (2018). Reproductive management in dairy cows - the future. Irish Veterinary Journal, 71(1). doi: 10.1186/s13620017-0112-y.

Fedorovych, V.V. (2017). Vplyv pokaznykiv vidtvornoyi zdatnosti na formuvannya molochnoyi produktyvnosti koriv symental's'koyi porody. Naukovyy visnyk L'vivs'koho natsional'noho universytetu veterynarnoyi medytsyny ta biotekhnolohiy imeni S.Z. Hzhyts'koho, 19(74), 52-56. doi: 10.15421/nvlvet7412 (in Ukrainian).

Heringstad, B., Chang, Y.M., Andersen-Ranberg, I.M., \& Gianola, D. (2006). Genetic analysis of number of mastitis cases and number of services to conception using a censored threshold model. J. Dairy Sci., 89(10), 4042-4048. doi: 10.3168/jds.S00220302(06)72447-X.

Kuziv, M.I. \& Fedorovych, E.I. (2016). Reppoductive ability of ukrainian black and white dairy cows. Scientific Messenger LNUVMBT named after S.Z. Gzhytskyj, 18, 2(67), 120-123. doi: 10.15421/nvlvet6727 (in Ukrainian).

Lakin, G.F. (1990). Biometrija: uchebnoe posobie [dlja biol. spec. vuzov]. Moskow, Vysshaja shkola (in Russian).

Shcherbatyy, Z.Ye., Bodnar, P.V., \& Kropyvka, Yu.H. (2017). Molochna produktyvnist' ta vidtvorna zdatnist' koriv ukrayins'koyi chorno-ryaboyi molochnoyi porody riznykh typiv konstytutsiyi. Naukovyy visnyk L'vivs'koho natsional'noho universytetu veterynarnoyi medytsyny ta biotekhnolohiy imeni S.Z. Hzhyts'koho, 19(74), 182-187. doi: 10.15421/nvlvet7440 (in Ukrainian).

Stavetska, R.V. \& Rudyk, I.A. (2012). Vplyv henotypovykh faktoriv na vidtvorni pokaznyky koriv. Tekhnolohiya vyrobnytstva i pererobky produktsiyi tvarynnytstva - Manufacturing and processing of animal products, 7(90), 39-43 (in Ukrainian).

Sudarev, N. (2008). Udoi i servis-period vzaimosvjazany. Zhivotnovodstvo Rossii, 3, 49-51 (in Russian).

Zubets, M.V. (2003). Vybranitvory. Uporiadnyk B.Ya. Panasiuk (in Ukrainian). 